UDC 347.21

DOI https:// doi.org/10.32850/LB2414-4207.2020.14.16

\title{
ANALYSIS PATENT ACTIVITY OF ORGANIZATIONS AND MANUFACTURERS CONCERNING PHARMACEUTICAL PRODUCTS
}

\author{
Rustamli Fidan Ali gizi, \\ PhD Student \\ (Azerbaijan National \\ Academy of Sciences, \\ Baku, Azerbaijan)
}

The aim of the study is to analyze the activity of pharmaceutical organizations and manufacturers taking into account the benefit of patients as well as public health conditions and assess good manufacturing practices for pharmaceutical products.

To summarize, it is noted that since drug development involves many risks, and because every successful drug molecule is the basis of extensive clinical research and development that takes decades, the patent begins well before drug development. Most countries grant 20 years of patent protection for innovative drugs. Much of this time is wasted in the application and approval process, so it is natural for any innovative company to resort to methods that extend the monopolization period, in particular the practice of greening a patent to recover damages. the huge costs they incur on R\&D.

The research methodology is based on logical, pharmaceutical and sociological concepts, qualitative and quantative research methods as well as document screening.

The scientific novelty of the research is the cross-sectional analysis of the activity of pharmaceutical companies, identifying causes and results of "evergreening" problem.

Conclusions. It is emphasized that improving legislation in one country without the application of appropriate measures by countries around the world may seem ineffective and destructive from the point of view of public health and health of a country that has allowed itself to reduce the level of patent protection. Thus, the author has proved that there is a direct relationship between the degree of patent protection in a state and the speed of new drugs entering its market: if strong patent rights accelerate the import of relevant drugs, then weak patent rights impede the import and increase the availability of harmful drugs. It appears that patent gardening contributes to unfair competition and related abuses. It notes that tighter controls on intellectual property around the world could eradicate such practices, widely adopted by innovative companies, in order to create a gateway for generic companies seeking to provide safe and effective medicines to the general public at cost-effective prices.

Key words: patent, medicinal products, dominant position, subsidiary. 


\title{
АНАЛІЗ ПАТЕНТНОЇ ДІЯЛЬНОСТІ ОРГАНІЗАЦІЙ І ВИРОБНИКІВ ЩОДО ФАРМАЦЕВТИЧНОЇ ПРОДУКЦЇ̈
}

\author{
Рустамлі Фідан Алі кизи, \\ докторант \\ (Національна академія \\ наук Азербайджану, \\ м. Баку, Азербайджан)
}

Метою дослідження $є$ аналіз діяльності фармацевтичних організацій і виробників з урахуванням користі для пацієнтів, а також стану здоров'я населення та оцінки належної практики виробництва фармацевтичних продуктів.

Підбиваючи підсумки, відзначається, що, оскільки розробка ліків пов'язана 3 багатьма ризиками й оскільки кожна успішна молекула лікарського засобу $\epsilon$ основою великих клінічних досліджень і розробок, які займають десятиліття, патент починається задовго до розробки лікарського засобу. Більшість країн надають 20 років патентного захисту інноваційних ліків. Білыша частина цього часу витрачається даремно на процес подачі заявки й отримання дозволу на вихід на ринок, тому для будь-якої інноваційної компанії природно вдаватися до методів, що збільшує період монополізації, зокрема до практики екологізації патенту для відшкодування збитків - величезних витрат, які вони несуть під час науково-дослідних і дослідноконструкторських робіт.

Методологія дослідження грунтується на логічних, фармацевтичних і соціологічних концепціях, якісних і кількісних методах дослідження, а також на перевірці документів.

Наукова новизна дослідження - це крос-секційний аналіз діяльності фармацевтичних компаній, виявлення причин і результатів проблеми «вічнозелених».

Висновки. Підкреслюється, що поліпшення законодавства в одній країні без застосування відповідних заходів країнами всього світу може бути неефективним i деструктивним із боку громадського здоров'я та охорони здоров'я країни, яка дозволила собі знизити рівень патентного захисту. Таким чином, автор довів пряму залежність між ступенем патентного захисту в державі й швидкістю виходу нових ліків на його ринок: якщо сильні патентні права прискорюють імпорт відповідних ліків, то слабкі патентні права перешкоджають імпорту й збільшенню доступності шкідливих для здоров'я ліків. Схоже, що патентне садівництво сприяє розвитку недобросовісної конкуренції та пов' язаних із цим зловживань. Відзначається, що жорсткіший контроль над інтелектуальною власністю в усьому світі міг би викоренити таку практику, яка широко застосовується інноваційними компаніями, щоб створити шлюз для компанійвиробників дженериків, які прагнуть надавати безпечні й ефективні ліки широкому загалу за економічно ефективними цінами.

Ключові слова: патент, лікарські засоби, заявка.

Introduction. Patents are the exclusive ownership of the intangible creations of the human mind. They exist only by the laws of sovereign states that can apply if a patent application is filed covering a territory. Patents are granted for any inventions, regardless of whether they are a product or a method, in all fields of technology, provided that they are novel, contain an inventive step and are industrially applicable.

Patents work in different areas. In the electronics industry, patents are often transferred to competitors through fundraising or printing licensing. This sharing is necessary because one product has many patented technologies. However, in the pharmaceutical, chemical, 
and biotech industries, a patent is usually equivalent to a product, and the necessary research protects a large investment in clinical trials. Patent protection for chemical and pharmaceutical products is especially important when compared to other industries because the actual manufacturing process is often easily replicable and can be copied with a fraction of the investment required for research and clinical trials.

The aim of the study is to analyze the activity of pharmaceutical organizations and manufacturers taking into account the benefit of patients as well as public health conditions and assess good manufacturing practices for pharmaceutical products.

The research methodology is based on logical, pharmaceutical and sociological concepts, qualitative and quantative research methods as well as document screening.

The scientific novelty of the research is the cross-sectional analysis of the activity of pharmaceutical companies, identifying causes and results of "evergreening" problem.

Perpetual greening problem of drug patents. A patent is a property right granted by a sovereign state to the inventor of a new, unclaimed and useful invention. Because the invention must be new (the meaning of which was not previously disclosed anywhere in the world), and because it cannot be discovered, it is a person who owns an art, and the transfer of property rights cannot prevent the public from acquiring what exists. The patent owner has the right to exclude the development, use, sale or sale of another invention within 20 years from the filing of another patent application.

A patent is a form of insurance for innovative pharmaceutical companies. It is known that the greatest risk to manufacturers is associated with prescription drugs. Prescription products are classified into therapeutic categories. Although patents formally prohibit competitors from withdrawing analog drugs before the patent expires, patents do not prevent the manufacture and sale of different drugs for the treatment of the same disease in a given therapeutic category. One such category is COX-2 inhibitors, which are commonly used in the treatment of arthritis. There are various types of prescription and over-the-counter drugs available on the market to treat this condition. Non-steroidal anti-inflammatory drugs (NSAIDs), which are subject to COX-2 inhibitors, are used to treat pain and inflammation associated with arthritis. COX-2 inhibitors are relatively recent and have gained paramount importance due to their ability to reduce the side effects of gastric bleeding and ulcers compared to the prescription of more traditional NSAIDs. However, some of the COX-2 drugs cause serious side effects that affect the heart. Also, COX-2 products are significantly more expensive than prescription NSAIDs. The cost comparison factor is also taken into account when prescribing a drug to a patient. Every patent for an innovative drug that expires requires huge investments for both innovator companies and generic firms and consumers.

Innovative companies are seeking to extend the validity of their patents by registering new invention solutions such as treatment methods, mechanism of action, isomeric forms, delivery profiles, dosage regimen and range, combinations, screening methods, biological targets, and application. As the patent life cycle increases, innovative companies maximize revenues from their "evergreen" products, thereby virtually eliminating any early competition.

Greening patent strategies that are commonly used in the pharmaceutical industry include the following.

Redundant expansion and creation of new generation drugs patented as modern drugs (brand migration). The various points (aspects) of innovative drugs include delivery profiles, manufacturing methods, chemical intermediates, formulations, dosage regimen, isomeric forms, mechanism of action and treatment method, etc. Often, innovators use one of these aspects to obtain additional patents shortly before the expiration of the main patent. Therefore, if a branded pharmaceutical company formulates a new molecule to treat a specific disease, 
the company is eligible for patent protection for different aspects of the parent drug, these additional patents covering different aspects of the same drug will add a term to the total duration of the original patent and limit launch of generic. For example, when the Prilosec patent was nearing its end, AstraZeneca, to maintain its monopoly on Prilosec, released Nexium, which was the same drug with minor changes in design and color [4].

Exclusive partnerships with generic market participants before patent expiration, which significantly increases brand value and allows for product royalties in the interim.

This antitrust practice is widely used by innovative companies that are trying to prevent an appropriate generic drug from entering the market. For example, pioneer companies negotiate with generic manufacturers to delay the time to market for specific generics. A prime example is a tamoxifen, marketed by the pharmaceutical company Astra Zeneca under the trade name Novaldex. Astra Zeneca and generic manufacturer Barr have reached an agreement whereby Astra Zeneca has committed a one-time payment of \$ 66.4 million to delay the release of a generic drug for up to 10 years. Apart that, Barr was able to market tamoxifen, created by AstraZeneca under the Barr brand. Another example is the agreement between AstraZeneca and the Indian generics manufacturer Torrent Pharmaceuticals, under which Torrent has committed itself to the production and supply of generics to the emerging markets of AstraZeneca [5]. The opposite variant of anticompetitive agreements is an agreement between manufacturers of generic drugs directly.

The practice of defensive pricing strategies, when innovative companies reduce the price of a product and bring it in line with the prices of other market players for healthy competition.

Following this practice, innovative companies start selling the cheaper version of the brandname drug as soon as the patent expires, thereby lowering the price of generic counterparts, leaving competitors far behind. Thus, as a result, prices for generics may fall by $40 \%$ or more within two years [6].

Subsidiaries are created by relevant innovative companies before competitors emerge. Pharmaceutical giants have recently shown increasing interest in setting up subsidiaries of generic companies and entering into partnerships with major generic manufacturers before competition from generic players increases. Over the past decade, Big Pharma companies have acquired small, one-stop divisions to expand their business model. [5].

\section{US policy}

In 1984, the US passed the Hatch-Waxman Act to find a balance between the interests of generic and innovative drug manufacturers. It was proposed to find this balance using certain provisions, useful both for the manufacturer of generics and for the companiesinnovators. Thus, the said law contains a provision on the remuneration of the generic manufacturer who is the first to challenge the innovator's patent. The first generic applicant, if successful in challenging the patent, receives a 180-day exclusive period, which allows the generic manufacturer to sell its products exclusively. The 180-day exclusive period recognizes the public interest in encouraging generic manufacturers to release generic versions of innovative medicines and to block the unjustified monopolies enjoyed by green patents. Under the Hatch-Waxman Act, a new procedure has been introduced whereby a generic drug manufacturer can file an ANDA (Abbreviated New Drug Application) application with the US Food and Drug Administration (FDA). The fundamental fact behind this scheme is that if an innovative drug is already approved, then it will need to demonstrate identical biological effects to obtain authorization and market launch of its generic version, and not to repeat clinical trials over and over again. To balance the interests of the innovative companies, the law requires a generic applicant to choose one of four certifications about the patent status of a competing generic:

- the point I - the medicine is not patented; 
- point II - the term of the drug patent has expired;

- clause III - the patent expires by the time the generics appear on the market;

- clause IV - the patent will not be infringed or the patent is invalid [8].

\section{EU policy}

There are not many laws in the European Union on the prevention of perpetual greening, but it should be noted that perpetual greening in the European Union is considered an abuse of dominant position and is regulated under Art. 102 Treaty on the Functioning of the European Union (TFEU). Because a patent is an exclusive right granted to the patentee, and the patent owner has the right to use the patent monopoly, the actions of the copyright holder cannot always be considered an abuse of dominant position. Evergreen appears to be forcibly included within the scope of Art. 102, therefore, this article needs a narrow and clear definition to be consistent with the concept of evergreen, since the existing definition is too broad and it seems impossible to use this provision.

\section{India politics}

In India, there is increased lobbying against the inclusion of data exclusivity clauses for the pharmaceutical and agrochemical sectors, as this is believed to be in the interest of the state. Moreover, it is pointed out that the inclusion of such provisions could have a huge impact on the generic pharmaceutical industry and could delay the entry of cheaper drugs into the market. The inclusion of a data exclusivity clause in the Indian intellectual property regime would also entail the concept of patent greening.

Under Indian law, new forms of already known substances are not patented unless proven to increase the known potency of a previously known substance. The purpose of introducing such a limitation was to limit the practice of perpetual gardening. Section 3 (d) limits the patentability of certain newer forms of older substances if they do not meet the requirement for enhanced performance criteria. Thus, the law states that "the discovery of a new form of a known substance that does not lead to an increase in the known effectiveness of this substance, or the discovery of any new property or new use of a known substance, or the use of a known method, cannot be patented, Thus, legislation sets higher patentability standards for new forms of already known substances. Moreover, such a provision has already established itself as an effective provision in the examination of evergreen patents.

Interesting in the context of the greening theme is the decision of the Supreme Court of India to refuse to grant a patent to the Swiss pharmaceutical company Novartis for a new version of the anti-cancer drug Gleevec (active ingredient is imatinib mesylate). According to Novartis, the patented drug is more readily absorbed into the bloodstream than previously patented drugs and, given that it is used to combat leukemia, this is sufficient to provide patent protection. As a result of six years of proceedings, the Court found that, according to patent law, to provide patent protection, a new version of an old drug must demonstrate increased efficiency [1]. Interesting, Moreover, at the time of these decisions, India was the first country in the world to take this step. Today, this practice is becoming widespread: in particular, the Moscow Arbitration Court on January 25, 2019, satisfied the claim of Nativa LLC for the issuance of a compulsory license to use a patent for a drug with INN sunitinib owned by Sugen LLC and Pharmacia \& Upjohn Company. Note that since 1995, more than a hundred attempts have been made to obtain compulsory licenses [3]. About antitrust regulation, the Federal Antimonopoly Service of the Russian Federation takes an active position on the issue of banning greening of patents, introducing bills and draft bylaws for consideration. In developed countries such as the United States, the European Union, and the Russian Federation, patent laws are too lenient to have a positive effect on reducing the number of evergreen patents. India is doing the opposite. As shown in the Novartis case, India has given a clear indication that the government will not risk public health and health 
care in general by allowing perpetual greening of drug patents. The Novartis decision sent a powerful signal to the world and innovative firms that India would only grant an extended market monopoly to pharmaceutical companies if it was demonstrated that a drug was indeed innovative and significantly improved in efficacy. Although the mechanisms are not yet established, and the actions of government agencies are often criticized, on the whole, an approach aimed at eliminating green patents seems to be correct.

Conclusions. It is emphasized that improving legislation in one country without the application of appropriate measures by countries around the world may seem ineffective and destructive from the point of view of public health and health of a country that has allowed itself to reduce the level of patent protection. Thus, the author has proved that there is a direct relationship between the degree of patent protection in a state and the speed of new drugs entering its market: if strong patent rights accelerate the import of relevant drugs, then weak patent rights impede the import and increase the availability of harmful drugs. It appears that patent gardening contributes to unfair competition and related abuses. It notes that tighter controls on intellectual property around the world could eradicate such practices, widely adopted by innovative companies, in order to create a gateway for generic companies seeking to provide safe and effective medicines to the general public at costeffective prices.

\section{References:}

1. Alice de Pastor. Latest news of medicinal products SPCs in Europe, 29th Alice de Pastors' SPC News, October 2016. URL: http://thespcblog.blogspot.com/2012/05/latestnews-on-medicinal-product-spcs.html.

2. Graul A.I., Sorbera L., Pina P., Tell M., Cruces E., Rosa E., Stringer M., Castañer R., Revel L. The year's new drugs \& biologics 2009. Drug News \& Perspectives. 2010. No. 23 P. 1.

3. Graul A.I., Cruces E., Stringer M. The year's new drugs \& biologics 2014. Part I. Drugs of Today. 2015. No. 51 (1). P. 37-87.

4. Katzka C. Interpretation of the term "product" in EU Council Regulations 1768/92 and 1610/96 on Supplementary Protection Certificates. Journal of Intellectual Property Law E Practice. 2008. No. 3 (10). P. 650-59.

5. Kyle M. Economic analysis of supplementary protection Ccertificates in Europe, unpublished mimeo, European Commission. 2017. URL: https://ec.europa.eu/growth/ industry/policy/intellectual-property/patents/supplementary-protection-certificates_en. 